\title{
HOW FUNCTIONAL MEASUREMENT OF THE TRADITIONAL FOODS CAN RAISE THE KNOWINGNESS OF OLD RECIPES USED IN ROMANIA AND DIASPORA
}

\author{
Luigi Fillippo D'ANTUONO \\ Universita di Bologna, email: filippo.d'antuono@unibo.it \\ Carmen COSTEA \\ Spiru Haret University Bucharest, email: cecostea@ yahoo.com ${ }^{1}$ \\ Larisa MIHOREANU \\ Academy of Economic Studies Bucharest, email: lmihoreanu@yahoo.com \\ Adrian VASILE \\ Erste Bank Vienna, email: Vasile_adrian0505@yahoo.com
}

\begin{abstract}
The present research continues a European project on "sustainable exploitation of bioactive components from the Black Sea Area traditional foods". Known as Base Food, it was a collaborative program, funded by European Union under the $7^{\text {th }}$ Framework Programme, few years ago. The initial research brought together scientists from countries situated around the Black Sea together with consultants from Italy, United Kingdom, Greece, Portugal and Serbia. Farther the medical, nutritional and technological approaches (Campos S., Doxey J., \& Hammond D., 2011, pp. 1496-1506) in the initial project, the Romanian team initiated a unique and outstanding valuable contribution and extended the local research towards socio-economic tracks. Thus, specific aspects were analysed and detailed within certain doctoral programmes. The present paper is emphasizing farther elements, remained collateral, when the main research was considered.
\end{abstract}

Keywords: sustainable development, healthy food, traditional food, consumer awareness

JEL Classification: I15, N50, Q18

\section{Introduction}

Base Food aimed to promote robust development and processing of specific identified traditional products containing emerging bioactive compounds with significant health effects in the Black Sea Region. The Base Food objectives focused on:

- Investigation of the fundamental knowledge of national foods and identify those representatives for the research purposes;

- Characterisation of nutrient and bioactive data (European Commission, Directorate General for Health and Consumers, 2009) for a subset of about 30

\footnotetext{
${ }^{1}$ Corresponding address
} 
prioritised traditional foods using previously developed and validated by another European project - Euro FIR (www.eurofir.org) with appropriate definition and analyses (Trichopoulou A., et al., 2006, pp. 498-504);

- Analysis of human intervention and address specific requirement for supporting evidence in nutrition and health claims (The European Parliament and the Council of the European Commission 2006, pp. 3-18; Wills J.M., et al., 2012, pp. 229-236);

- Evaluation of processors and consumers attitudes to enhance the food chain and improve its management and availability and health benefits;

- Dissemination of any findings and results to sustain and gain more awareness in the traditional foods production and consumption in order to improve health.

The project objectives, entirely congruent with international researches in the world, made a significant contribution to the substantiation of nutrition/health claims for traditional food (Lynam A., McKevitt A., Gibney M.J., 2011, pp. 2213-2219) and enhanced the cooperation between researchers and stakeholders to promote robust development of SMEs in the Black Sea Region. (European Commission, 2010, pp. 16-18)

The "traditional" elements characterize foods used for ages in smaller or broader local societal groups (Guerrero L., et al., 2009, pp. 345-354); their recipes have been perpetuated from one generation to another either from mouth to mouth or in writing. Even today, traditional foods (Commission of the European Communities, 2006b, pp. 1-11) represent important elements of diets, despite the difficult recover under the rapacious globalisation. The most challenging approaches are to save traditional diets - at least those culturally important and health promoting. The methodological context underlining this work was recently shared under some research project, such as Euro FIR Network of Excellence (2005-2010) (www.eurofir.org), or the Base Food project (2009-2012) (www.basefood-fp7.org).

The registration of traditional foods requires comprehensive documentation (Dilis V., Vasilopoulou E., Trichopoulou A., 2011) about all elements linked to the food traditionality. Other related cultural information refers to the etymology of the food's name, the recipes' evolution and its importance in the local diet, economy, community life, and other features involving consumption. (Trichopoulou A., Soukara S., Vasilopoulou E., 2007, pp. 420-427)

The preparation procedures (Commission of the European Communities, 2006a, pp. 12-25; Dilis V., Vasilopoulou E., Trichopoulou A., 2011) of the traditional food follow the interest for nutritional (Mejean C., et al., 2012) information and composition. They include all empirical methods and technical parameters: temperatures, utensils etc. allowing reproduction of the recipe without major deviations from the original product. Nutritional analyses (Costa H.S., et al., 2010, pp. 73-81) are always conducted by accredited laboratories (Patterson N.J., Sadler M.J., Cooper J.M., 2012, pp. 121-130) for macronutrients and selected vitamins and minerals. However, the determination of other compounds is recommended - such as the flavonoids in the plant products. Depending on the food, microbiological analysis might also be necessary for safety or quality issues (e.g. for fermented products). In specific circumstances, sensory evaluation brings complementary information. 
An important phase of the local analysis on a triple survey referred to Romanians' consumption of traditional food, both in Romania and Diaspora. To reach such goal, the Romanian team decided to do a supplementary survey addressed to Romanian emigrants, western consumers found within the country, to check the awareness and the attitude of westerners towards traditional foods as possible new versions of ethnic foods. Further the chosen foods analysed within the project, more products were considered in our complementary survey: plum jam, dried fruits and green vegetables dish, garlic sauce, hotchpotch of fresh vegetable, nettles dish.

\section{Deepening the research beyond boarders}

Given the importance of the topic for the Romanian team, more objectives were added to be considered both at local level and across Diaspora:

- Before the analysis, the assessment of the nature and functionality of our traditional products for a better understanding of all processes and their effects on health together with specific generation of data basis standards;

- Initiation and application of specific surveys to obtain information regarding the awareness, knowledge and acceptance of traditional food dishes from the Black Sea area (www.basefood.eu, Mazoyer, M. L., Laurence, R., 2006); this stage was followed by an accurate process of verification prior to carry out the questionnaire analysis in Romania and in specific locations in four Western European countries where Romanian population is mostly present (Italy, Spain, France and Portugal);

- Construction of a complete report on how the functional measurement of the traditional foods can raise the knowingness of old recipes used in Romania and Diaspora.

The questionnaires for Romanian emigrants to Western Europe were distributed in four major locations: Italy, Spain, France and Portugal. The figure 1 portrays the place of residence for Romanian emigrants that were interviewed during the data gathering:

Figure 1. Current residence of respondents

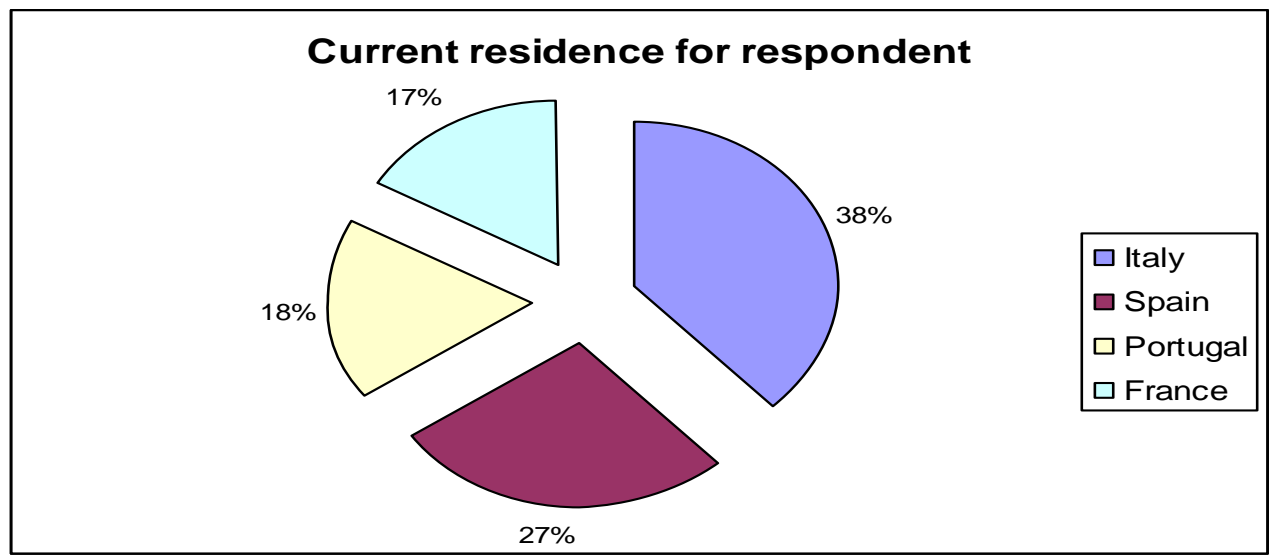


The questionnaires regarding immigrants to Romania were distributed in major locations in Romania, in the Bucharest extended area, most notably Baneasa Airport, Crangasi Square, Baneasa, Auchan, Carrefour Baneasa, Cora Sun Plaza, Cora Lujerului. Both table 1 and figure 2 portray the place in which the interview took place as well the frequency attributed to each location for migrants to Romania:

Table 1

\section{Customer Organisation}

\begin{tabular}{|l|c|c|c|c|} 
& Frequency & Percent & $\begin{array}{c}\text { Valid } \\
\text { Percent }\end{array}$ & $\begin{array}{c}\text { Cumulative } \\
\text { Percent }\end{array}$ \\
\hline Bucharest City Centre & 41 & 27.3 & 27.3 & 27.3 \\
\hline Auchan & 13 & 8.5 & 8.5 & 35.8 \\
\hline Baneasa Airport & 5 & 3.3 & 3.3 & 39.1 \\
\hline Billa Bucharest & 4 & 2.6 & 2.6 & 41.7 \\
\hline Carrefour Orhideea & 6 & 3.4 & 3.4 & 45.1 \\
\hline Carrefour Baneasa & 4 & 2.6 & 2.6 & 47.7 \\
\hline Cora & 3 & 2 & 2 & 49.7 \\
\hline Cora Lujerului & 11 & 7.3 & 7.3 & 57 \\
\hline Cora Lujerului Subway & 14 & 9.1 & 9.1 & 66.1 \\
\hline $\begin{array}{l}\text { Cora Subway Piata } \\
\text { Sudului }\end{array}$ & 6 & 4 & 4 & 70.1 \\
\hline $\begin{array}{l}\text { Cora Subway } \\
\text { Republica }\end{array}$ & 1 & 0.7 & 0.7 & 70.8 \\
\hline Cora Sun Plaza & 8 & 5.3 & 5.3 & 76.1 \\
\hline Mega Image & 6 & 3.9 & 3.9 & 80 \\
\hline Metro & 10 & 7.5 & 7.5 & 87.5 \\
\hline NIC & 8 & 5.2 & 5.2 & 92.7 \\
\hline Piata Crangasi & 6 & 3.9 & 3.9 & 96.6 \\
\hline Piata Obor & 2 & 1.4 & 1.4 & 98 \\
\hline Selgros & 3 & 2 & 2 & 100 \\
\hline Total & 153 & 100 & 100 & \\
\hline
\end{tabular}

These questionnaires were filled and collected between March and July 2011. After initial checking, the data was introduced and coded into SPSS. The data set has been updated by eliminating invalid questionnaires and incomplete answers. 
Figure 2. Consumers Organisation

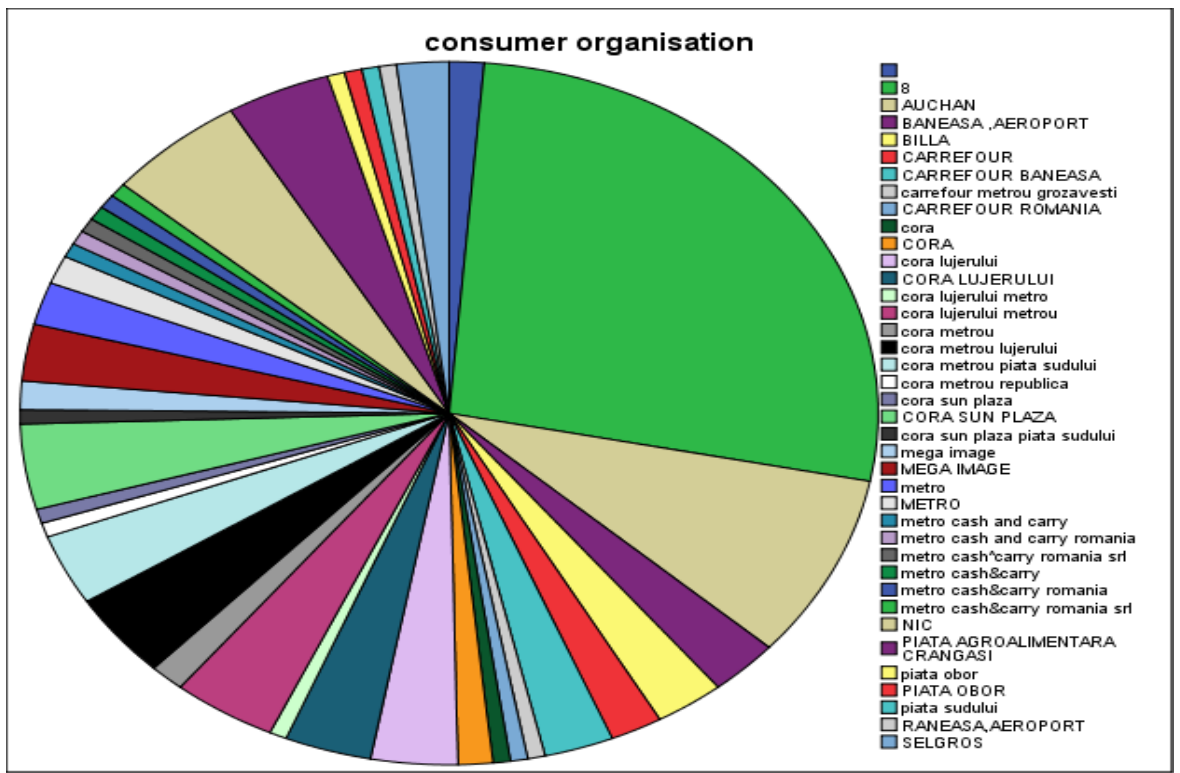

Increasing the Awareness about the Traditional Food among Romanian Emigrants to Western Europe

One of the first concerns of the study was to identify whether the Romanian emigrants included in the data collection process played an active role in the decision regarding the acquisition of food products.

Figure 3. Involvement in the buying food process

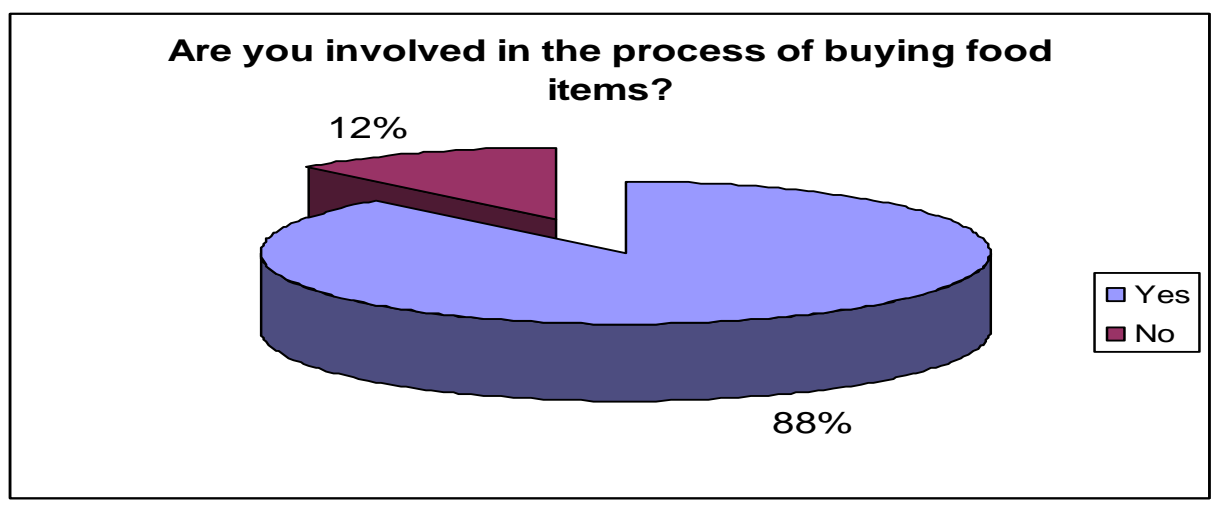

Approximately $88 \%$ of respondents claimed that they were actively involved in the action of buying food items. The remaining $12 \%$ claimed that they did not take part in this process. The latter had not been withdrawn from the study since 
the objective was to establish the degree of knowledge and awareness among the entire population of Romanian migrants.

The source for acquisition was very important to determine the possibility to introduce traditional food products in the mainstream of commercial production. The table 2 indicates the main sources for buying food according to the respondents:

Table 2

The main sources for the acquisition of food products

\begin{tabular}{|lr|}
\hline Supermarket & 53.65 \\
\hline Discount store & 6.36 \\
\hline Public market & 24.09 \\
\hline Farm & 5.75 \\
\hline Grocery & 9.38 \\
\hline Other & 0.87 \\
\hline Total & 100 \\
\hline
\end{tabular}

The data from table 2 is also represented in the figure 4:

Figure 4. Acquiring food products sources

\section{The source for acquiring food products}

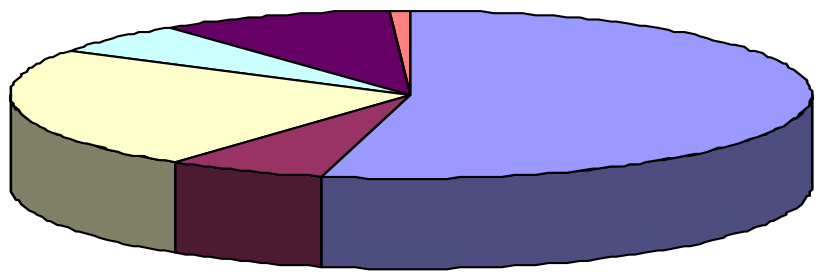

\begin{tabular}{|l}
$\square$ Supermarket \\
$\square$ Discount store \\
$\square$ Public market \\
$\square$ Farm \\
$\square$ Grocery \\
$\square$ Other
\end{tabular}

In the questionnaire, the supermarket category was also set to incorporate the hypermarkets and other large stores that sell a very large variety of products (foodstuff and other). Supermarkets and other large sellers account for approximately $54 \%$ of the food products declared by Romanian migrants, thus, any effort in the mass production and mass selling of traditional food products would have to take into consideration the inclusion of these location in their distribution chains.

The frequency of food preparation helps illustrate the actual market potential for traditional food products as it can be linked positively with the average number of hours spent for shopping and concurrently, can be linked negatively with the number of visits to specialized restaurants. It can be assumed that individuals, who 
prepare food products less often, needed their nourishment prepared and possibly sold by others.

The following figure (5) captures the data regarding food preparation. It can be asserted that $64 \%$ of respondents are involved in preparing food at least a few times per week, thus they would represent the potential customers for traditional ingredients or semi prepared food products that can be distributed through supermarkets (and hypermarkets), traditional market places, grocery stores.

On the other hand, the remaining $36 \%$ of respondents, that have expressed their relative lack of interest in preparing their own food, would represent the potential market for traditional restaurants. The fact that they do not prepare their own food during the week represents a strong incentive for this part of the migrants to become customers for vendors specialized in fresh dishes.

Figure 5. Frequency of food preparation

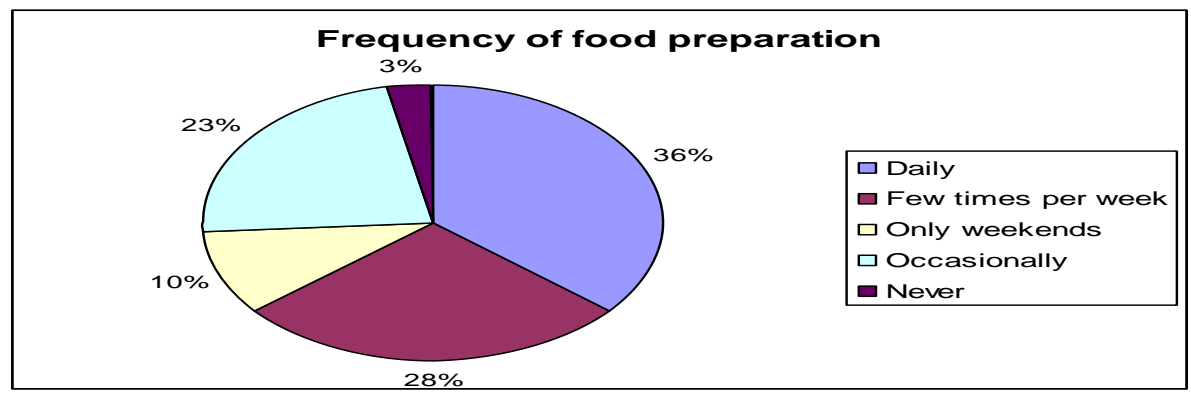

The fact that $89 \%$ of respondents usually consume dishes previously prepared at home, support the latter idea of them forming a great potential market for traditional ingredients. On the other hand, the relatively reduced percentage of individuals the habit of eating out indicates a reduced potential for new traditional restaurants that would target solely Romanian migrants in Western Europe. Ingredients and semi prepared traditional food items can more easily be put up for sale as they require a minimum of preparation and less specific means for serving.

Figure 6. Sources for prepared food

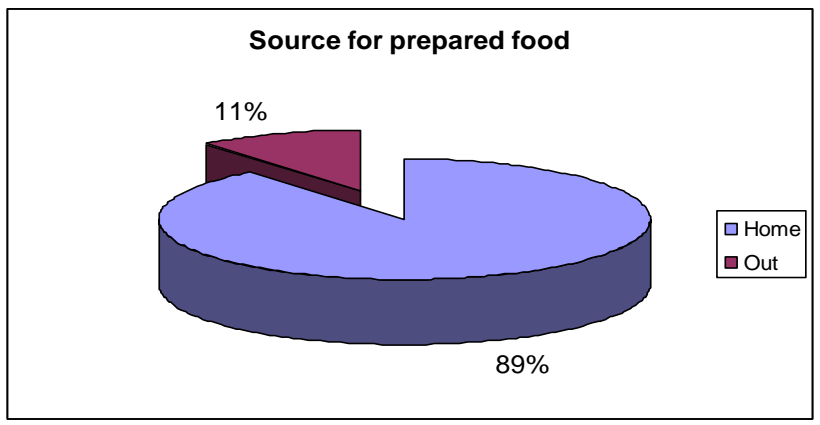


Figure 7. Food preparation

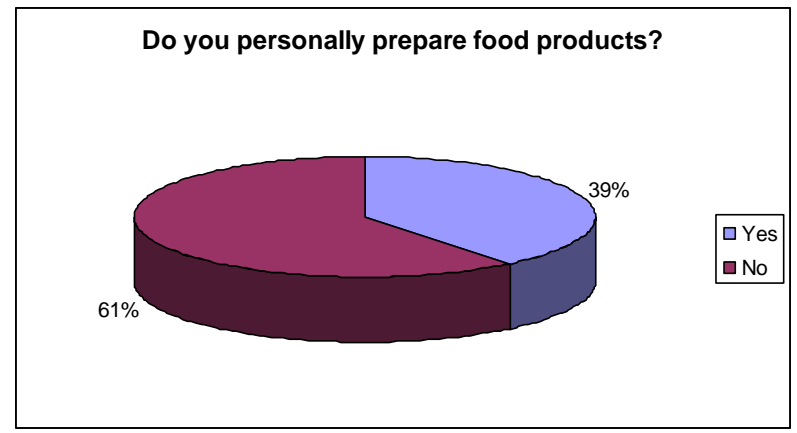

Approximately $89 \%$ preferred to dine at home while $61 \%$ of respondents felt personally involved in the preparation of food products.

The study participants were also asked to provide their own suggestions for traditional Romanian products prior to knowing the list of selected prioritized food items (selected by the Base Food team). Over 50 food products were suggested. Among these, "sarmale", potato based products ("cartofi") and "ciorba de burta" (pig stomach soup) were the most frequent answers.

\section{Carrying out the questionnaire analysis in Romania and in specific locations of Diaspora}

Once the questionnaire collection over all the methods and tools already mentioned were applied to get more results, following the Brussels indications and the collateral goal additionally considered. The total number and structure of questionnaires retrieved by the Romanian team can be seen in the table 3:

Table 3

The questionnaires typology and location

\begin{tabular}{|c|c|c|}
\hline Type & Quantity & Location \\
\hline Marketers & Total 20 & \\
\hline & $4+16$ & $\begin{array}{l}\text { Bucharest (including } 14 \text { through the MIC.RO private } \\
\text { network) }\end{array}$ \\
\hline Nutritionists & Total 48 & $\begin{array}{l}\text { Institute of Nutrition Related Illnesses and Diabetes } \\
\text { Dr. Paulescu }\end{array}$ \\
\hline & $\begin{array}{c}37 \\
1 \\
1 \\
2 \\
2 \\
5\end{array}$ & $\begin{array}{l}\text { Bucharest } \\
\text { Suceava } \\
\text { Adjud } \\
\text { Focsani } \\
\text { Fetesti } \\
\text { Bacau }\end{array}$ \\
\hline Technologists & Total 21 & The Patronate of Food Industry ROMALIMENTA \\
\hline
\end{tabular}




\begin{tabular}{|c|c|c|}
\hline \multirow[t]{10}{*}{ Type } & Quantity & Location \\
\hline & 1 & Bacau \\
\hline & 1 & Brasov \\
\hline & $4+4$ & Bucharest-ROMPAN \\
\hline & 1 & Constanta \\
\hline & 1 & Covasna \\
\hline & 4 & Galati \\
\hline & 1 & Iasi \\
\hline & 1 & Ludus \\
\hline & 2 & Tulcea \\
\hline \multirow[t]{6}{*}{ Local Population } & Total 152 & \\
\hline & 70 & Supermarkets Bucharest \\
\hline & 41 & Supermarkets Targu Jiu \\
\hline & 8 & Open food markets Bucharest \\
\hline & 28 & Subway Bucharest \\
\hline & 5 & Airport Baneasa (Mall) \\
\hline \multirow[t]{16}{*}{ Emigrants } & Total 103 & \\
\hline & 45 & Italy (online) \\
\hline & 32 & Italy Rome \\
\hline & 7 & Italy Torino \\
\hline & 6 & Italy Milano \\
\hline & $17+15$ & Spain \\
\hline & $9+15$ & Spain Madrid \\
\hline & 1 & Spain Seville \\
\hline & 2 & Spain Valladolid \\
\hline & 3 & Spain Valencia \\
\hline & 1 & Spain Altea \\
\hline & 1 & Spain Saragoza \\
\hline & 21 & Portugal \\
\hline & 11 & Portugal Porto \\
\hline & 10 & Portugal Lisbon \\
\hline & 20 & France Lyon Association of Promoting Performance \\
\hline
\end{tabular}

Constructing a complete report on the awareness, knowledge and acceptability of traditional food for Romanian emigrants to Western Europe and for immigrants to Romania

Based on the information provided by data centralisation from the questionnaires regarding the consumer awareness and knowledge of products the following conclusions can be supported:

1. From the prioritised Romanian traditional foods, someone who likes cabbage leaf rolls (sarma) with dehydrated plums and apples scores very low in all 
categories. They are known by less than $50 \%$ of migrants, consumed at least once by less than $30 \%$, occasionally consumed by only $20 \%$ and remained favourite food for less than $5 \%$ of respondents.

2. Products that are very well known, frequently consumed and form the favourite food of a large percentage of migrants in Western Europe are: Cornmeal mush polenta (Mămăligă), Eggplant salad, Nut horns.

3. Other important traditional foods, when it comes to the awareness of migrants are: Elderberry soft drink (Socata), Plums jam (sugar free) Gem de prune, Vegetables soup/cream, Green beans dish, Pumpkin pie.

4. The "problem products" requiring special attention and marketing measures refer to: Vegetables soup with caraway and semolina, Spinach with dill and mint, Onion stuffed with rice, Onion pie.

5. On a scale from 1 to 10 , the data show that the most important characteristic for traditional food (according to migrants) are: taste (average score of 9.29), healthiness (average score of 9.06), lack of alteration (average of 9.02). The less important characteristics are: availability in daily diet (average of 5.51), availability in restaurants (average of 6.18), spicy flavour (average of 3.68), lack of sophistication (average of 6.39), green packing (average of 6.75), and organic (average of 6.7), the capacity to be stored (average of 6.18), ability to be prepared with the microwave oven (average of 5.09).

The finalisation of this research could be followed by other follow-up projects to which the Romanian team participated with renewed efforts and aspirations.

During the project development some bottlenecks became obvious: a) the preparation of questionnaires regarding the understanding the socio-economic concepts by the other specialist (non-economists) inside the projects; b) the lack of communication during numerous dialogues developed between specialists with different expertise and backgrounds; c) the questionnaire processing stage caused by some divergent tools and programs supposed to be used.

Despite those bottlenecks, the scientists found out collateral ways to understand traditional foods connected to the results and the right values of traditions, initiated new visions and new missions with confidence, to contribute at a greener, sounder, more prosperous market and society.

\section{References}

1. Albala, K. (ed.) (2011) Food Cultures of the World Encyclopaedia, ABC-CLIO, CA, USA.

2. Banu, C. (1974) Influenta proceselor tehnologice asupra calității produselor alimentare. Bucureşti: Editura Tehnica.

3. Babaita C. (2000) Studiul merceologic al produselor alimentare. Timişoara: Editura Mirton.

4. Banu C. (1982) Produsele alimentare şi inocuitatea lor. Bucureşti: Editura Tehnica.

5. Bateman, H., Curtis, S., McAdam, K. (2006) Dictionary of Agriculture. $3^{\text {rd }}$ Ed. A\&C Black Publishers Ltd, London, UK.

6. Bilteanu, G. and Birnaure, V. (1979) Fitotehnie. Bucureşti: Editura Ceres. 
7. Campos S., Doxey J., Hammond D. (2011) Nutrition labels on pre-packaged foods: a systematic review. Public Health Nutrition 14:1496-1506.

8. Commission of the European Communities (2006a). Council Regulation (EC) No $510 / 2006$ of 20 March 2006 on the protection of geographical indications and designations of origin for agricultural products and foodstuffs. Official Journal of the European Union, L93:12-25.

9. Commission of the European Communities (2006b). Council Regulation (EC) No $509 / 2006$ of 20 March 2006 on agricultural products and foodstuffs as traditional specialties guaranteed. Official Journal of the European Union, L93:1-11.

10. Costa H.-S., Vasilopoulou E., Trichopoulou A., Finglas P., Participants of EuroFIR Traditional Foods Work Package (2010) New nutritional data on traditional foods for European food composition databases. Eur J ClinNutr, 64S3:73-81.

11. Costa H.-S., Albuquerque T.-G., Sanches-Silva A., Finglas P. (2011) Deliverable 2.3 Report on analytical data on traditional foods to be available for inclusion in the appropriate national FCDB and EuroFIR datasets Sustainable exploitation of bioactive components from the Black Sea Area traditional foods (BaSeFood Project). (www.basefood-fp7.eu) [29.12.2014].

12. Dilis V., Vasilopoulou E., Trichopoulou A. (2011) Deliverable 1.3 - Flow charts on the preparation procedure of the composite traditional foods accompanied if possible by audiovisual material. Sustainable exploitation of bioactive components from the Black Sea Area traditional foods (BaSeFood Project). (www.basefood-fp7.eu) [29.12.2014].

13. Dilis V., Vasilopoulou E., Trichopoulou A. (2011) Deliverable 1.5 - Specific integrated reports on the selected individual foods. Sustainable exploitation of bioactive components from the Black Sea Area traditional foods (BaSeFood Project). (www.basefood-fp7.eu) [29.12.2014].

14. The European Parliament and the Council of the European Commission (2006) Corrigendum to Regulation (EC) No 1924/2006 of the European Parliament and of the Council of 20 December 2006 on nutrition and health claims made on foods. Official Journal of the European Union L12:3-18.

15. European Commission (2010) Regulation (EU) No 116/2010 of 9 February 2010 amending Regulation (EC) No 1924/2006 of the European Parliament and of the Council with regard to the list of nutrition claims. Official Journal of the European Union L37:16-18.

16. The European Parliament and the Council of the European Commission (2011) Regulation (EU) No 1169/2011 on the provision of food information to consumers, amending Regulations (EC) No 1924/2006 and (EC) No 1925/2006 of the European Parliament and of the Council, and repealing Commission Directive 87/250/EEC, Council Directive 90/496/EEC, Commission Directive 1999/10/EEC, Directive 2000/13/EC of the European Parliament and of the Council, Commission Directives 2002/67/EC and 2008/5/EC and Commission Regulation (EC) No 608/2004. Official Journal of the European Union L304:18-62.

17. European Commission, Directorate General for Health and Consumers (2009) Working document on the setting of nutrient profiles. Preliminary draft legal proposal. Brussels, Belgium, February 2009

18. Guerrero L., Guàrdia M.D., Xicola J., Verbeke W., Vanhonacker F., ZakowskaBiemans S., Sajdakowska M., Sulmont-Rossé C., Issanchou S., Contel M., Scalvedi M.L., Granli B.S., Hersleth M. (2009) Consumer-driven definition of traditional food 
products and innovation in traditional foods. A qualitative cross-cultural study. Appetite 52:345-54.

19. Lynam A., McKevitt A., Gibney M.J. (2011) Irish consumers' use and perception of nutrition and health claims. Public Health Nutrition 14:2213-9.

20. Mazoyer M. L., Laurence R. (2006) A history of world agriculture - From the Neolithic Age to the Current Crisis, Earthscan, London, UK.

21. Mejean C., Macouilard P., Peneau S., Hercberg S., Castetbon K. (2012) Perception of front-of-pack labels according to social characteristics, nutritional knowledge and food purchasing habits. Public Health Nutrition doi:10.1017/S1368980012003515.

22. Mocanu S., Raducanu D. (1989) Plante medicinale. Legume, fructe si cereal in terapeutica. Ed. Militara, Bucharest, Romania.

23. Mohan G., Avram A. (1989) Valorificarea resurselor vegetale in gospodarie si industrie. Ed. Tehnica, Bucharest, Romania.

24. Murariu M., Murariu D., Haş V., Study of old maize landraces from northern Moldavia and Transylvania, N. I.N.C.D.A. Fundulea, Vol. LXXVIII, NR. 2, 2010, Online ISSN 2067-7758 www.incda-fundulea.ro.

25. Onete D., et al (1963) Merceologia produselor alimentare. Ed. Didactica si Pedagogica, Bucharest, Romania.

26. Patterson N.J., Sadler M..J., Cooper J.M. (2012) Consumer understanding of sugars claims on food and drink products. Nutrition Bulletin 37:121-130.

27. Roman R.A. (1998), Bucate, vinuri, obiceiuri româneşti, Editura PAIDEIA.

28. Schiop T.V., Variabilitatea conținutului de amidon şi fibre la populaţii locale şi sintetice, Linii consangvinizate şi hibrizi de porumb, PhD thesis, 2011.

29. Svederberg E., Wendin K. (2011) Swedish consumers' cognitive approaches to nutrition claims and health claims. Food \& Nutrition Research 55:5929 doi:10.3402/ fnr.v55i0.5929

30. Trichopoulou A., Vasilopoulou E., Georga K., Soukara S., \& Dilis V. (2006) Traditional foods: why and how to sustain them. Trends in Food Science and Technology 17:498-504.

31. Trichopoulou A., Soukara S., Vasilopoulou E. (2007) Traditional foods: a science and society perspective. Trends in Food Science \& Technology 18:420-427.

32. Trichopoulou A., Vasilopoulou E., Hollman P., Chamalides C., Foufa E., Kaloudis T., Kromhout D., Miskaki P., Petrochilou I., Poulima E., Stafilakis K., Theophilou D. (2000). Nutritional composition and flavonoid content of edible wild greens and green pies: A potential rich source of antioxidant nutrients in the Mediterranean diet. Food Chemistry, 70:319-323.

33. Wills J.M., Storcks S., Bonsmann G., Kolka M., Grunert K.G. (2012) Symposium 2: Nutrition and health claims: help or hindrance European consumers and health claims: attitudes, understanding and purchasing behaviour. Proceedings of the Nutrition Society 71:229-236.

34. www.basefood-fp7.org

35. www.basefood.eu

36. www.eurofir.org 